\title{
Long-term effectiveness of live herpes zoster vaccine in patients with rheumatoid arthritis subsequently treated with tofacitinib
}

Herpes zoster (HZ) incidence is higher in patients with rheumatoid arthritis (RA) compared with the general population, ${ }^{1}$ and it may be further increased with disease-modifying antirheumatic drugs (DMARDs). ${ }^{2}$ Tofacitinib is an oral Janus kinase inhibitor for the treatment of RA. Real-world data indicate that 
HZ incidence is approximately twofold higher with tofacitinib versus biologic DMARDs (bDMARDs). ${ }^{3}$

Current American College of Rheumatology guidelines conditionally recommend that patients with RA aged $\geq 50$ years receive $\mathrm{HZ}$ vaccine prior to tofacitinib or bDMARDs. ${ }^{4}$ We previously evaluated the immunogenicity of a live attenuated zoster vaccine (LZV), administered 2-3 weeks prior to tofacitinib or placebo with background conventional synthetic DMARDs. Both groups had similar varicella zoster virus (VZV)-specific immune responses, and overall immune responses were comparable with those of healthy volunteers in previous studies. ${ }^{5} \mathrm{We}$ have now followed this patient cohort in an open-label, longterm extension (LTE) study of tofacitinib.

Patients enrolled in the index study (A3921237; NCT02147587) 5 could join ORAL Sequel (LTE study; A3921024; NCT00413699) 14 weeks post-vaccination, where they received open-label tofacitinib 5 or $10 \mathrm{mg}$ two times per day (online supplementary figure S1); background RA therapy was also allowed. Patients were followed for 27 months. Postvaccination, adverse events (AEs), including discontinuations due to AEs, were recorded during the study within 28 days of the last dose. Incidence rates (IRs; patients with events/100 patientyears (PY)) and 95\% CIs for HZ post-vaccination were calculated based on time to first event (patients not reporting an event were censored at last treatment dose). Short-term VZV-specific immunity was evaluated at baseline and week 6 post-vaccination during the index study.
Vaccine-related AEs in the index study included mild injectionsite pain, swelling, redness, itching and myalgia. Disseminated vaccine-strain varicella was also reported in a patient with no previous exposure to VZV. ${ }^{5}$ After rollover into ORAL Sequel, 100 patients received an average tofacitinib dose of $5 \mathrm{mg}(\mathrm{n}=46)$ or $10 \mathrm{mg}(\mathrm{n}=54)$ two times per day. Mean (range) tofacitinib exposure was 489 (46-811) days and overall exposure was 139 PY.

LZV did not provide adequate protection to all patients. Five HZ cases (\#1-5) occurred in the LTE study 218, 280, 748,741 and 544 days post-vaccination, respectively (IR $=3.60$ (1.17, 8.39); table 1). Cases \#1-4 were monodermatomal and case \#5 involved five dermatomes. All HZ events were mild/ moderate in severity and resolved with antiviral treatment.

VZV humoral immunity (immunoglobulin G (IgG) titre) and VZV cell-mediated immunity (interferon- $\gamma$ enzyme-linked immunosorbent spot (ELISPOT)) in patients receiving tofacitinib or placebo in the index study ${ }^{5}$ are shown in table 1. In terms of immunity after LZV in this analysis, cases \#1, \#4 and \#5 had undetectable VZV cell-mediated immunity, at baseline and week 6 ; cases \#2 (patient received tofacitinib $5 \mathrm{mg}$ two times per day in index and LTE studies) and \#3 (patient received placebo and tofacitinib $5 \mathrm{mg}$ two times per day in index and LTE studies, respectively) responded adequately to vaccination by both IgG and ELISPOT measures but had lower than average VZV IgG levels at baseline (case \#2: $36.9 \mathrm{U} / \mathrm{mL}$ vs average of $201 \mathrm{U} / \mathrm{mL}$; case \#3: $96.6 \mathrm{U} / \mathrm{mL}$ vs average of $182 \mathrm{U} / \mathrm{mL}$ ) and week 6 (case \#2: $70.9 \mathrm{U} / \mathrm{mL}$

\begin{tabular}{|c|c|c|c|c|c|}
\hline & Case \#1 & Case \#2 & Case \#3 & Case \#4 & Case \#5 \\
\hline Age, years & 65 & 60 & 77 & 74 & 74 \\
\hline Sex & Female & Male & Female & Male & Male \\
\hline Race & White & White & White & White & White \\
\hline $\begin{array}{l}\text { Study drug } \\
\text { (A3921237) }\end{array}$ & $\begin{array}{l}\text { Tofacitinib } \\
5 \mathrm{mg} \text { two times per day }\end{array}$ & $\begin{array}{l}\text { Tofacitinib } \\
5 \mathrm{mg} \text { two times per day }\end{array}$ & Placebo & Placebo & Placebo \\
\hline $\begin{array}{l}\text { Study drug } \\
\text { (ORAL Sequel) }\end{array}$ & $\begin{array}{l}\text { Tofacitinib } \\
10 \mathrm{mg} \text { two times per day }\end{array}$ & $\begin{array}{l}\text { Tofacitinib } \\
5 \mathrm{mg} \text { two times per day }\end{array}$ & $\begin{array}{l}\text { Tofacitinib } \\
5 \mathrm{mg} \text { two times per day }\end{array}$ & $\begin{array}{l}\text { Tofacitinib } \\
10 \mathrm{mg} \text { two times per day }\end{array}$ & $\begin{array}{l}\text { Tofacitinib } \\
10 \mathrm{mg} \text { two times per day }\end{array}$ \\
\hline Background RA drugs & $\begin{array}{l}\text { MTX } 15 \mathrm{mg} / \text { week } \\
\text { Prednisone } 5 \mathrm{mg} / \text { day }\end{array}$ & MTX $20 \mathrm{mg} /$ week & None & None & MTX $20 \mathrm{mg} /$ week \\
\hline Type of HZ & Monodermatomal & Monodermatomal & Monodermatomal & Monodermatomal & 5 dermatomes \\
\hline Severity of $\mathrm{HZ}^{*}$ & Moderate & Mild & Moderate & Mild & Mild \\
\hline Duration of $\mathrm{HZ}$, days & 49 & 14 & 14 & 16 & 10 \\
\hline Action to study drug & No action taken & Stopped temporarily & No action taken & No action taken & Stopped temporarily \\
\hline Outcome of $\mathrm{HZ}$ & Resolved with acyclovir & Resolved with famciclovir & $\begin{array}{l}\text { Resolved with acyclovir } \\
\text { and azithromycin }\end{array}$ & $\begin{array}{l}\text { Resolved with } \\
\text { valacyclovir }\end{array}$ & $\begin{array}{l}\text { Resolved with } \\
\text { valacyclovir }\end{array}$ \\
\hline \multicolumn{6}{|l|}{ Occurrence of $\mathrm{HZ}$} \\
\hline Time after LZV vaccination, days & 218 & 280 & 748 & 741 & 544 \\
\hline Time after initiation of tofacitinib, days & 202 & 267 & 702 & 699 & 466 \\
\hline \multicolumn{6}{|l|}{ VZV humoral immunity (IgG titre), U/mL $†$} \\
\hline Baseline & 224.3 & 36.9 & 96.6 & 237.3 & 208.3 \\
\hline Week 6 & 444.0 & 70.9 & 186.9 & 231.5 & 222.5 \\
\hline Change from baseline (fold rise at week 6) & 1.98 & 1.92 & 1.93 & 0.98 & 1.07 \\
\hline \multicolumn{6}{|l|}{ VZV cell-mediated immunity, SFCs $/ 10^{6}$ PBMCs $\ddagger$} \\
\hline Baseline & 25 & 41 & 25 & 25 & 25 \\
\hline Week 6 & 25 & 76 & 51 & 25 & 25 \\
\hline Change from baseline (fold rise at week 6) & 1.00 & 1.85 & 2.04 & 1.00 & 1.00 \\
\hline
\end{tabular}

${ }^{*}$ Determined by the investigator.

†Assessed by gpELISA (PPD Vaccines and Biologics); mean VZV IgG titres in patients receiving tofacitinib and placebo, respectively, in the index study were 201 and $182 \mathrm{U} / \mathrm{mL}$ at baseline and 403 and $323 \mathrm{U} / \mathrm{mL}$ at week 6 (fold rise at week 6 was 2.11 with tofacitinib and 1.74 with placebo). ${ }^{5}$

¥Assessed by IFN $\gamma$ ELISPOT (Pfizer Inc Vaccine Research Unit, Pearl River, New York, USA); limit of detection was 25 SFCs/10 $0^{6}$ PBMCs; values in the table shown as 25 SFCs/10 $0^{6}$ PBMCs may be below this threshold; mean VZV cell-mediated immunity in patients receiving tofacitinib and placebo, respectively, in the index study was 48 SFCs/10 ${ }^{6}$ PBMCs and 43 SFCs $/ 10^{6}$ PBMCS at baseline, and 70 SFCs $/ 10^{6}$ PBMCs and 56 SFCs $/ 10^{6}$ PBMCs at week 6 (fold rise at week 6 was 1.50 with tofacitinib and 1.29 with placebo).

ELISPOT, enzyme-linked immunosorbent spot; gpELISA, glycoprotein-based enzyme-linked immunosorbent assay; HZ, herpes zoster; IFN $\gamma$, interferon gamma; IgG, immunoglobulin G; LZV, live zoster vaccine; MTX, methotrexate; PBMCs, peripheral blood mononuclear cells; RA, rheumatoid arthritis; SFCs, spot-forming cells; VZV, varicella zoster virus. 
vs average of $403 \mathrm{U} / \mathrm{mL}$; case \#3: $186.9 \mathrm{U} / \mathrm{mL}$ vs average of $323 \mathrm{U} / \mathrm{mL}$; table 1 ).

$\mathrm{HZ}$ incidence was similar to that in patients receiving tofacitinib in phase $1 / 2 / 3 / \mathrm{LTE}$ studies up to 9.5 years $(\mathrm{IR}=3.6$ $(3.4,3.9) ; \mathrm{n}=782 / 7061]),{ }^{6}$ although the present analysis was limited due to the small number of patients, and 95\% CIs were wide. Cell-mediated responses in cases \#2 and \#3 may have been short-lived; however, serial longitudinal data are required to confirm this.

These results suggest that LZV may not provide adequate long-term protection, as previously demonstrated in healthy individuals aged $\geq 60$ years 3 years post-vaccination, in which $\mathrm{HZ}$ risk was reduced by $51 \%{ }^{2}$ While it is possible that LZV booster vaccinations may improve vaccine efficacy, to date there is a lack of data on the use and timing of booster vaccinations, and no recommendations on the use of LZV booster vaccinations currently exist. This highlights the importance of evaluating the newly approved subunit non-live vaccine (Shingrix) in patients with RA receiving tofacitinib.

Kevin L Winthrop ๑ , ${ }^{1}$ Ann Wouters, ${ }^{2}$ Ernest H Choy, ${ }^{3}$ Connie Chen, ${ }^{2}$ Pinaki Biswas, ${ }^{2}$ Lisy Wang, ${ }^{4}$ Koshika Soma, ${ }^{4}$ Elie Needle, ${ }^{2}$ Hernan Valdez, ${ }^{2}$ William FC Rigby

${ }^{1}$ Oregon Health \& Science University, Portland, Oregon, USA

2Pfizer Inc, New York, New York, USA

${ }^{3}$ CREATE Centre, Division of Infection and Immunity, Cardiff University School of Medicine, Cardiff, UK

${ }^{4}$ Pfizer Inc, Groton, Connecticut, USA

${ }^{5}$ Geisel School of Medicine at Dartmouth, Lebanon, New Hampshire, USA

Correspondence to Kevin LWinthrop, MD, MPH, OHSU-PSU School of Public Health, 3181 S.W. Sam Jackson Rd, Portland, OR 97239, USA; winthrop@ohsu.edu

Handling editor Josef S Smolen

Acknowledgements The authors would like to acknowledge Lisa McNeil for managing the ELISPOT assay and for her contributions to the interpretation of the ELISPOT and ELISA results. Medical writing support, under the guidance of the authors, was provided by Anthony G McCluskey, PhD, CMC Connect, McCann Health Medical Communications and was funded by Pfizer Inc, New York, New York, USA in accordance with Good Publication Practice (GPP3) guidelines (Ann Intern Med 2015;163:461-464).

Contributors All authors were involved in the analysis and interpretation of data, critically revising the text for important intellectual content. All authors agree to be accountable for all aspects of the work and read and approved the final version to be published.

Funding This study was sponsored by Pfizer Inc.

Competing interests KLW has acted as a consultant for AbbVie, Bristol-Myers Squibb, Eli Lilly, Galapagos, Gilead, Pfizer Inc and UCB; and he has received grant/ research support from Bristol-Myers Squibb. EHC has received grant/research support from BioCancer, Pfizer Inc, Roche and UCB; has acted as a consultant for Amgen, Biogen, Chugai Pharma, Eli Lilly, Janssen, Novartis, Pfizer Inc, Regeneron, Roche, R-Pharm and Sanofi; and has participated in speakers' bureaus for Amgen, Boehringer Ingelheim, Bristol-Myers Squibb, Chugai Pharma, Eli Lilly, Hospira, MSD, Novartis, Pfizer Inc, Regeneron, Roche, Sanofi-Aventis and UCB. WFCR has received grant/research support from Pfizer Inc and has acted as a consultant for Pfizer Inc and Roche. AW, CC, PB, LW, KS, EN and HV are employees and shareholders of Pfizer Inc.

Patient and public involvement Patients and/or the public were not involved in the design, conduct, reporting or dissemination plans of this research.

Patient consent for publication Not required.

Provenance and peer review Not commissioned; externally peer reviewed. permits others to distribute, remix, adapt, build upon this work non-commercially, and license their derivative works on different terms, provided the original work is properly cited, appropriate credit is given, any changes made indicated, and the use is non-commercial. See: http://creativecommons.org/licenses/by-nc/4.0/.

(C) Author(s) (or their employer(s)) 2020. Re-use permitted under CC BY-NC. No commercial re-use. See rights and permissions. Published by BMJ.

- Additional material is published online only. To view please visit the journal online (http://dx.doi.org/10.1136/annrheumdis-2019-216566).

These data were presented at the American College of Rheumatology Annual Scientific Meeting in 2017 (Winthrop KL et al. Ann Rheum Dis 2017;76[Suppl 2]) and are used here with permission from John Wiley \& Sons, Inc.

\section{Check for updates}

To cite Winthrop KL, Wouters A, Choy EH, et al. Ann Rheum Dis 2020;79:669-671.

Received 31 October 2019

Revised 3 February 2020

Accepted 4 February 2020

Published Online First 11 March 2020

Ann Rheum Dis 2020;79:669-671. doi:10.1136/annrheumdis-2019-216566

ORCID iD

Kevin L Winthrop http://orcid.org/0000-0002-3892-6947

\section{REFERENCES}

1 Yun $\mathrm{H}$, Yang S, Chen L, et al. Risk of herpes zoster in autoimmune and inflammatory diseases: implications for vaccination. Arthritis Rheumatol 2016;68:2328-37.

2 Winthrop KL, Furst DE. Rheumatoid arthritis and herpes zoster: risk and prevention in those treated with anti-tumour necrosis factor therapy. Ann Rheum Dis 2010;69:1735-7.

3 Curtis JR, Xie F, Yun $\mathrm{H}$, et al. Real-world comparative risks of herpes virus infections in tofacitinib and biologic-treated patients with rheumatoid arthritis. Ann Rheum Dis 2016;75:1843-7.

4 Singh JA, Saag KG, Bridges Jr SL, et al. 2015 American College of Rheumatology guideline for the treatment of rheumatoid arthritis. Arthritis Rheumatol 2016:68:1-26.

5 Winthrop KL, Wouters AG, Choy EH, et al. The safety and immunogenicity of live zoster vaccination in patients with rheumatoid arthritis before starting tofacitinib: a randomized Phase II trial. Arthritis Rheumatol 2017;69:1969-77.

6 Cohen S, Tanaka Y, Mariette X, et al. Long-term safety of tofacitinib up to 9.5 years: a comprehensive integrated analysis of the RA clinical development program [abstract] Arthritis Rheumatol 2018;70:Abstract 963.

Open access This is an open access article distributed in accordance with the Creative Commons Attribution Non Commercial (CC BY-NC 4.0) license, which 